\title{
Contrasting Cenozoic Lithospheric Evolution and Architecture in the Western and Eastern Sino-Korean Craton: Constraints from Geochemistry of Basalts and Mantle Xenoliths
}

\author{
Yi-Gang Xu, Sun-Lin Chung, ${ }^{1}$ Jinlong $M a$, and Lanbin Shi ${ }^{2}$ \\ Guangzhou Institute of Geochemistry, Chinese Academy of Sciences, 510640 Guangzhou, China \\ (e-mail: yigangxu@gig.ac.cn)
}

\begin{abstract}
A B S T R A C T
Cenozoic basalts from both sides of the Daxin'anling-Taihang gravity lineament that separates the Sino-Korean craton (SKC) into western and eastern parts have been studied. In the western SKC, magmas evolved from xenolith-bearing alkali basalts of Late Eocene-Oligocene age to coexisting alkali and tholeiitic basalts of Late Miocene-Quaternary age. This change in basalt type is accompanied by a decrease in $\mathrm{La} / \mathrm{Yb}$ and an increase in $\mathrm{Yb}$ content. Sr-Nd isotopic ratios and relative abundances on incompatible elements are consistent with a prevailing asthenospheric origin, although lithospheric mantle may have also contributed to these basalts. This temporal variation in basalt geochemistry is interpreted as reflecting progressive lithospheric thinning in the western SKC during the Cenozoic. An opposite trend is observed for Cenozoic basalts from the eastern SKC, suggesting lithospheric thickening during this time period. This thickening was probably related to regional thermal decay following peak magmatism in the Late Cretaceous-Early Tertiary. Such contrasting lithospheric processes may reflect diachronous extension in the SKC, with initial extension in the eastern part owing to the Late Mesozoic paleo-Pacific subduction and subsequent extension in the western SKC induced by the Early Tertiary Indian-Eurasian collision. An implication is that the lithospheric mantle in the western SKC is relatively old compared with that beneath the eastern SKC, which may be a mixture of old lithospheric relicts and newly accreted mantle. This predicted lithospheric architecture is consistent with Sr-Nd isotopic data and recent Re-Os age determinations from mantle xenoliths included in Cenozoic basalts.
\end{abstract}

\section{Introduction}

The Sino-Korean craton (SKC) in eastern China is an important natural laboratory for studying temporal change in the lithosphere because of the occurrence of Ordovician diamondiferous kimberlites, Mesozoic lamprophyre-basalt and Cenozoic basalts, and the presence of deep-seated xenoliths in these magmas (E and Zhao 1987; Liu et al. 1992b; $\mathrm{Lu}$ et al. 1995; Zhang et al. 2002). The SKC experienced widespread thermotectonic reactivations during the Late Mesozoic and Cenozoic, which resulted in replacement of the old, cold, thick, and depleted lithospheric mantle by young, hot, thin, 2004

Manuscript received November 18, 2003; accepted May 15, 1 Taipei, Taiwan.

${ }^{2}$ Institute of Geology, State Seismological Bureau, 100029 Beijing, China. and fertile mantle (Menzies et al. 1993; Griffin et al. 1998).

Several studies further suggest a partial replacement and that the subcontinental lithospheric mantle (SCLM) in this region consists of old lithosphere in the uppermost part and newly created "oceanic-type" lithosphere in the lower part (Fan et al. 2000; Xu 2001). These studies focused on the region east of the Daxin'anling-Taihang gravity lineament (DTGL), hereafter referred to as the eastern SKC (fig. 1). Despite studies of Miocene basalts and included xenoliths from Hannuoba (Song and Frey 1989; Song et al. 1990; Zhi et al. 1990; Basu et al. 1991; Tatsumoto et al. 1992; Gao et al. 2002; Xu 2002), little is known about the Cenozoic lithospheric evolution in the region west of the DTGL (i.e., the western SKC). In fact, basaltic volcanism is widespread in the western SKC and began in the Late Eocene and Oligocene and continued into the 


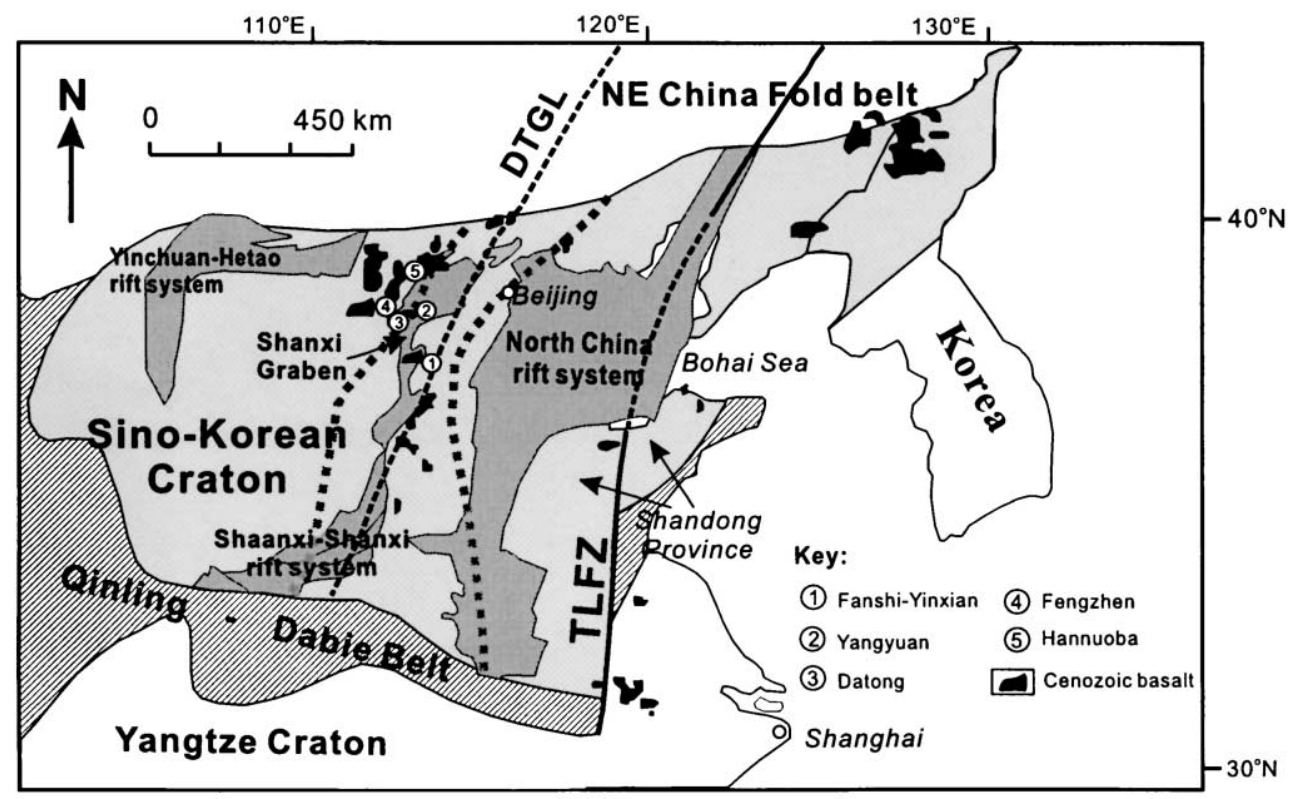

Figure 1. Simplified map showing distribution of Cenozoic rifting systems and basalts in the Sino-Korean craton (SKC), eastern China (modified after Xu 2002). Note that the SKC is cut by two major geological and geophysical linear zones: the Tan-Lu fault zone (TLFZ) to the east and the Daxin'anling-Taihang gravity lineament (DTGL) to the west. Two rift systems (Yinchuan-Hetao and Shaanxi-Shanxi) occur in the western SKC. The North China rift system is located in the eastern SKC. Two shaded and dashed lines outline the central zone that separates the western and eastern zones of the SKC (after Zhao et al. 2001).

Miocene and Quaternary (Fan and Hooper 1991; Liu et al. 1992b).

This article focuses on the western SKC basalts. Our objective is to use basalt geochemistry to define melting conditions and temporal change in the lithospheric thickness in the western SKC. We use the lithospheric lid model described by Ellam (1992) and Fram and Lesher (1993) and also compare basaltic evolution trends in the western and eastern SKC. In conjunction with xenolith data, inferences are made regarding the heterogeneous composition and architecture of the lithospheric mantle beneath the SKC. We also discuss the cause and mechanism for thermotectonic destruction of the lithospheric root beneath eastern China during Late MesozoicCenozoic time.

\section{Geologic Background}

The SKC, one of the oldest continental nuclei on earth (3.8-2.5 Ga; Jahn et al. 1987; Liu et al. 1992a), is crosscut by two large-scale geological and geophysical linear zones. To the east, the craton is cut by the Tan-Lu Fault Zone (TLFZ), which is associated with significant Cenozoic and Mesozoic volcanism. To the west, it is traversed by the north- south-trending DTGL (fig. 1), which separates two topographically and tectonically different regions (Ma 1989). Lowlands that include the Huabei Plain, the Bohai Sea, the highlands of Shandong, and the Liaodong Peninsula dominate the eastern SKC. During Late Mesozoic and Cenozoic time, this region experienced widespread lithospheric extension, producing the north-northeast-trending North China rift system and widespread volcanism (fig. 1). The crust beneath this region is thin $\mid<35$ $\mathrm{km}$ ) with a minimum crustal thickness of $\sim 28 \mathrm{~km}$ beneath the Bohai Sea. The regional Bouguer gravity anomaly is weakly negative to positive, and heat flow is high, so the lithosphere is inferred to be thin (<80-100 km; Ma 1989).

In contrast, the part of the western SKC that includes the Yan and Taihang Mountains and the Loess Plateau is characterized by thicker crust $>40$ $\mathrm{km})$, negative Bouguer gravity anomalies, and lower heat flow, all of which reflect a thick (>100$\mathrm{km}$ ) lithosphere (Ma 1989). Although widespread extension is absent, two isolated Cenozoic rift systems, the Yinchuan-Hetao rift and the ShaanxiShanxi rift, occur in the western SKC (fig. 1). The Shaanxi-Shanxi rift, a series of en echelon grabens, extends from the southern margin of the Loess Pla- 
teau north-northeastward across the plateau, delineating a roughly S-shape form. Although rifting started in the southern part of the Shaanxi-Shanxi rift system in the Late Eocene or Early Oligocene, major extension occurred in the Neogene and Quaternary (Ye et al. 1987; Ren et al. 2002). Rift activity apparently migrated from southwest to northeast during the Oligocene to Pliocene epochs (Ye et al. 1987). In contrast to the other parts of the North China rift system, most grabens in the ShaanxiShanxi rift lack volcanism, except in the Datong graben, where a series of volcanic rocks were erupted during the Late Eocene to Quaternary (fig. 1). Some of these mantle-derived rocks carry deepseated peridotite and pyroxenite xenoliths.

For this study, basalts were collected from five localities in the Datong graben and its adjacent regions, namely the Late Eocene Fanshi and Yinxian (38-40 Ma), the Oligocene Yangyuan (30-35 $\mathrm{Ma})$, the Miocene Fengzhen (7-14 Ma), and the Quaternary Datong $(<1 \mathrm{Ma})$ regions (Liu et al. $1992 b$ ). A brief summary of the petrographic characteristics of lavas from each locality, including phenocryst assemblages and grain sizes, degrees of alteration, and presence or absence of xenoliths, is presented in table 1. Most of the lavas are characterized by a phyric texture. Olivine is an almost ubiquitous phenocryst phase, often occurring with clinopyroxene (augite) and plagioclase (labradoritic composition). The groundmass ranges from glassy to cryptocrystalline. The identifiable components of the groundmass are olivine, plagioclase, clinopyroxene, and opaque minerals, mostly magnetite. The rocks are generally fresh with the only indication of altering being iddingsitization of olivine.

\section{Methodology}

Theoretical modeling suggests that only a small amount of melt can be produced from the lithospheric mantle by conduction of heat from the asthenosphere (McKenzie and Bickle 1988; Arndt and Christensen 1992). However, hydrous or veined lithospheric mantle may be a source of extensioninduced magmas (Gallagher and Hawkesworth 1992; Leeman and Harry 1993), whereas dry and refractory lithospheric mantle is likely to be a mechanical barrier that halts the upward progression of the asthenospheric melting column (Ellam 1992; Langmuir et al. 1992). Experimental studies also demonstrate that more $\mathrm{SiO}_{2}$-undersaturated (i.e., alkaline) magmas are produced at higher pressures than tholeiitic lavas (e.g., Falloon et al. 1988). For example, Nohda et al. (1991) reported that Cenozoic tholeiites in North China were generated at pressures of $15-20 \mathrm{kbar}(50-60 \mathrm{~km})$ and alkali basalts at $25-30 \mathrm{kbar}(>80 \mathrm{~km})$. Given that the lithospheric mantle and asthenosphere generally have different geochemical and isotopic signatures (Menzies 1990; DePaolo and Daley 2000), it can be

Table 1. Petrographic Characteristics of Cenozoic Basalts from the Western Sino-Korean Craton

\begin{tabular}{|c|c|c|c|c|c|c|c|c|c|c|}
\hline \multirow{2}{*}{$\begin{array}{l}\text { Locality and } \\
\text { rock type }\end{array}$} & \multicolumn{3}{|c|}{ Phenocryst } & \multicolumn{5}{|c|}{ Composition of groundmass phases } & \multirow[b]{2}{*}{ Alteration } & \multirow[b]{2}{*}{ Xenolith and xenocryst } \\
\hline & Mineral & $\%$ & $(\mathrm{Mm})$ & $\mathrm{Ol}$ & Plag & Cpx & Opaque & Glass & & \\
\hline \multicolumn{11}{|l|}{ Datong: } \\
\hline \multirow{2}{*}{ Alkali basalts } & $\mathrm{O} 1$ & $10-20$ & $.2-1.0$ & $5-10$ & $50-60$ & $5-15$ & $5-10$ & \multirow{5}{*}{$\begin{array}{c}\ldots \\
>80\end{array}$} & $\ldots$ & \multirow[t]{5}{*}{ Rare small peridotite } \\
\hline & $\mathrm{Ol}$ & $1-10$ & & \multirow{4}{*}{$<1$} & \multirow{4}{*}{$>70$} & \multirow{4}{*}{$<1$} & & & & \\
\hline \multirow{3}{*}{ Tholeiites } & $\mathrm{Ol}$ & $5-15$ & $.2-1.0$ & & & & \multirow{3}{*}{$<1$} & & \multirow[t]{3}{*}{$\ldots$} & \\
\hline & Plag & $5-15$ & $.2-.5$ & & & & & & & \\
\hline & Cpx & $5-20$ & $.2-1.0$ & & & & & & & \\
\hline \multicolumn{11}{|l|}{ Fangzhen: } \\
\hline \multirow[t]{3}{*}{ Ol basalts } & $\mathrm{Ol}$ & $5-10$ & $.2-2.0$ & \multirow[t]{3}{*}{$5-15$} & \multirow[t]{3}{*}{$40-70$} & \multirow[t]{3}{*}{$15-25$} & \multirow[t]{3}{*}{$<5$} & \multirow[t]{3}{*}{$5-20$} & \multirow[t]{3}{*}{ Idd, $<5 \%$} & \multirow[t]{3}{*}{$\ldots$} \\
\hline & Plag & $5-10$ & $.2-1.0$ & & & & & & & \\
\hline & Cpx & $1-5$ & $.5-1.5$ & & & & & & & \\
\hline \multicolumn{11}{|l|}{ Yangyuan: } \\
\hline \multirow[t]{2}{*}{ Alkali basalts } & $\mathrm{Ol}$ & $\sim 10$ & $.3-.7$ & \multirow[t]{2}{*}{$5-10$} & \multirow[t]{2}{*}{60} & \multirow[t]{2}{*}{$5-10$} & \multirow[t]{2}{*}{$<5$} & \multirow[t]{2}{*}{20} & \multirow[t]{2}{*}{$\ldots$} & Abundant peridotite \\
\hline & Plag & $1-10$ & $.2-.5$ & & & & & & & Feldspar megacrysts \\
\hline \multirow{4}{*}{$\begin{array}{l}\text { Yinxian: } \\
\text { Alkali basalts }\end{array}$} & & & & & & & & & & \\
\hline & $\mathrm{Ol}$ & $\sim 10$ & $.2-.5$ & $\sim 5$ & $>50$ & $10-20$ & $\sim 5$ & $10-20$ & Idd, $<10 \%$ & $\ldots$ \\
\hline & Plag & $5-10$ & $.2-.5$ & & & & & & & \\
\hline & Cpx & $\sim 5$ & $.2-1.0$ & & & & & & & \\
\hline Fanshi: & & & & & & & & & & \\
\hline Ol basalts & $\mathrm{Ol}$ & $\sim 5$ & $.1-.7$ & $\cdots$ & 55 & $25-30$ & $<2$ & $\cdots$ & Idd, $10 \%$ & Peridotite and rare \\
\hline & Plag & $20-30$ & $.5-1.0$ & & & & & & Vesicules & \\
\hline
\end{tabular}

Note. $\quad \mathrm{Ol}=$ olivine $; \mathrm{Cpx}=$ clinopyroxene $;$ Plag = plagioclase $; \mathrm{Idd}=$ iddingsite. 
inferred that the lithosphere is $>80 \mathrm{~km}$ thick if the alkali basalts have a SCLM isotopic signature. On the other hand, if the tholeiitic basalts have an asthenospheric signature, the lithosphere is inferred to be $<60 \mathrm{~km}$ thick. Because typical continental lithosphere extends to about a $100-\mathrm{km}$ depth and the crust is about $40 \mathrm{~km}$ thick, the depth for generating most basaltic magmas corresponds to the depth interval of typical SCLM prior to extension (DePaolo and Daley 2000). In the eastern SKC, studies have already shown that Mesozoic basalts indeed have a SCLM signature (negative $\varepsilon_{\mathrm{Nd}}$ and low $\mathrm{Nb} / \mathrm{La}$ ), in contrast to the dominant asthenospheric signature (positive $\varepsilon_{\mathrm{Nd}}$ and high $\mathrm{Nb} / \mathrm{La}$ ) observed in Cenozoic basalts (Xu 2001; Zhang et al. 2002). This temporal change in magma source has been interpreted as a result of loss of the lithospheric keel in Late Cretaceous time (Xu 2001; Xu et al. 2004).

Geochemistry of the asthenosphere-derived lavas is dependent on the melting interval between the depth at which the adiabatic geotherm crosses the mantle solidus and the depth of the lithosphereasthenosphere boundary (Langmuir et al. 1992). For example, the mean degree of partial melting is relatively smaller and melting depth is higher in regions with thick lithosphere. Accordingly, the geochemistry of basalts can be used to monitor variation in lithospheric thickness through time (Ellam 1992; Fram and Lesher 1993; DePaolo and Daley 2000; Wang et al. 2002). Assuming a lithospheric lid effect, alkali basalts are likely generated when the lithosphere is relatively thick $(>80$ $\mathrm{km})$, while the eruption of tholeiites is largely confined to zones of thinned lithosphere $(<60 \mathrm{~km})$. In a given region, a temporal transition from alkali to tholeiitic basalt may be accompanied by progressive lithospheric thinning due to convective removal or replacement of the lithosphere by the asthenosphere (Perry et al. 1987; Ellam 1992; Fram and Lesher 1993; Kerr 1994; DePaolo and Daley 2000). The opposite transition, from tholeiitic to alkali basalt, may be indicative of lithospheric thickening as the asthenosphere cools to form lithosphere.

Cenozoic basalts from the SKC are mostly asthenosphere derived with negligible crustal contamination (Zhou and Armstrong 1982; Peng et al. 1986; Song et al. 1990; Basu et al. 1991). Although some experienced interaction with the lithospheric mantle (see "Basaltic Evolution in the Western SKC from Progressive Lithospheric Thinning"), we envisage that the lithospheric lid effect would be, in the first order, significant in their genesis.

\section{Basaltic Evolution in the Western SKC from Progressive Lithospheric Thinning}

As seen from the total alkalis versus $\mathrm{SiO}_{2}$ plot (fig. $2 a)$, Late Eocene-Oligocene lavas from the western SKC are mainly alkali basalts with a few samples straddling the alkali-tholeiitic boundary. Among these samples, normative $\mathrm{Ne}$ is common, normative $\mathrm{Hy}$ is generally $<10 \%$ (with the exception of two analyses), and normative $\mathrm{Q}$ is absent (table 2). In contrast, the Miocene-Quaternary lavas are mainly tholeiitic, although alkali lavas are also found at Datong (fig. 2a). Among these younger lavas, normative $\mathrm{Q}$ is common, normative $\mathrm{Hy}$ is generally $>10 \%$ (mostly $>15 \%$ ), and normative $\mathrm{Ne}$ is absent. An overall subalkaline feature for the younger lavas is also clear from a normative $\mathrm{Ne}$ Ol-Q plot, in contrast to the alkaline feature of the older basalts (fig. 2b). This is consistent with relatively higher $\mathrm{SiO}_{2}$ contents in the MioceneQuaternary magmas at a given $\mathrm{MgO}$ compared to the pre-Miocene lavas. In addition, abundant peridotite and pyroxenite xenoliths occur in the Fanshi and Yangyuan basalts, but only rare peridotite xenoliths of small size $(<2 \mathrm{~cm})$ have been documented in the Datong lavas.

The Late Eocene-Oligocene lavas are characterized by enrichment in light rare earth elements (LREE), with $\mathrm{La} / \mathrm{Yb}$ ranging from 10 to 57 (fig. 3a). Specifically, lavas from Yangyuan show the strongest REE fractionation and the lowest heavy rare earth elements (HREE) among the samples analyzed (table 2). Despite some overlap, the MioceneQuaternary basalts tend to be lower in $\mathrm{La} / \mathrm{Yb}$ and higher in $\mathrm{Yb}$ content compared with the older lavas (fig. 3a). Given the similar $\mathrm{MgO}$ contents $(6 \%-9 \%)$ for the studied samples, such differences in trace element composition cannot be related to differentiation but are mostly related to the variable extent of partial melting or to heterogeneous sources. This is seen in figure 3, where melting trajectories of an enriched peridotite with different clinopyroxeme/garnet $(\mathrm{Cpx} / \mathrm{Gt})$ ratios are compared with the observed data. The observed trace element variation can be accounted for by variable degrees of partial melting of a source with the $\mathrm{Cpx} / \mathrm{Gt}$ ratio of $19: 1$ (fig. 3a). Specifically, samples with high $\mathrm{Yb}$ contents and low $\mathrm{La} / \mathrm{Yb}$ ratios are generated by a higher degree of melting compared with those with low $\mathrm{Yb}$ contents and high $\mathrm{La} / \mathrm{Yb}$ ratios. Alternatively, at a fixed melting degree, the former can be formed by melting a source containing a low proportion of garnet, whereas the latter are derived from a garnet-rich source. Although distinguishing between these alternatives is not straightforward, 

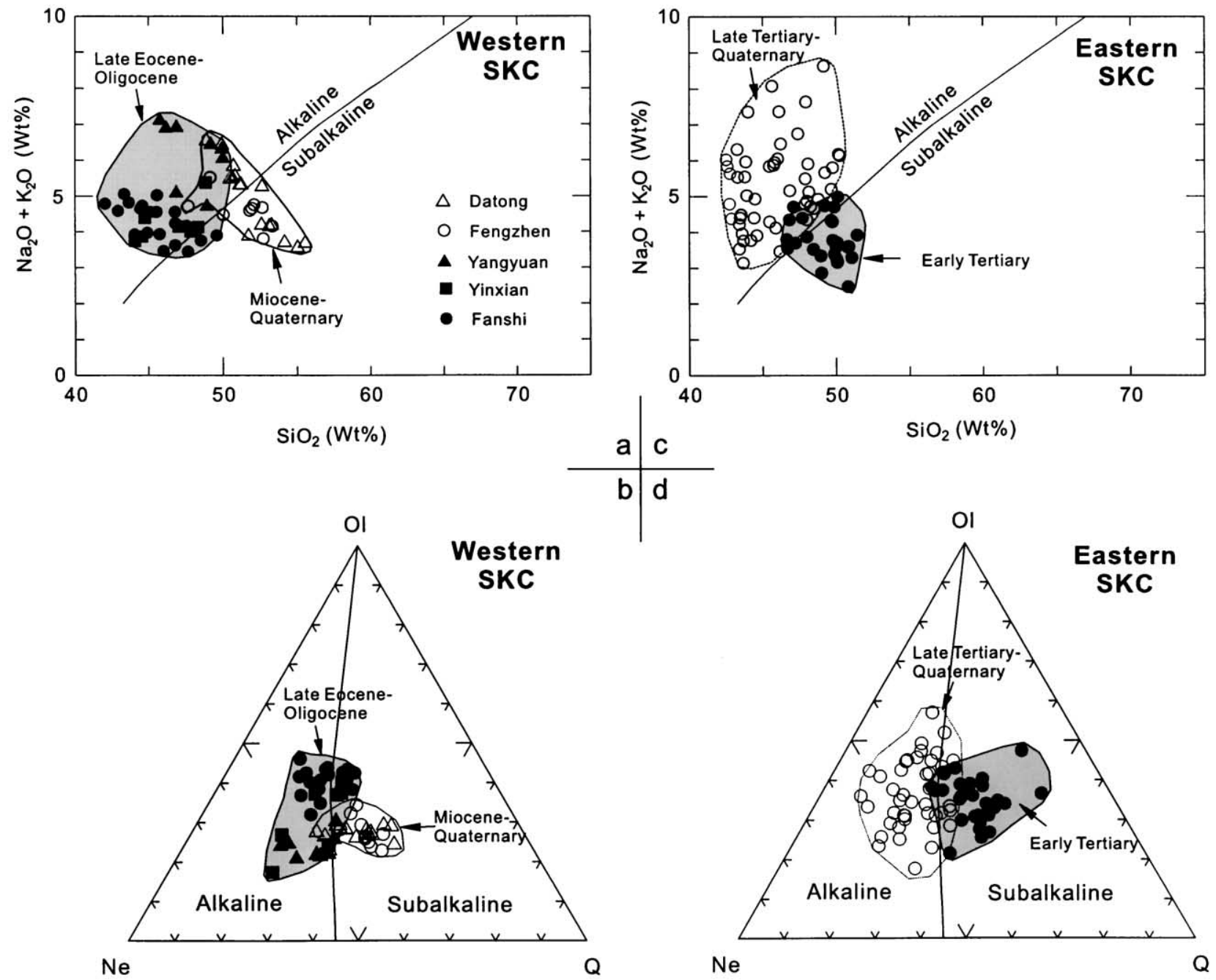

Figure 2. Basalt classification plots in terms of total alkalis $\left(\mathrm{Na}_{2} \mathrm{O}+\mathrm{K}_{2} \mathrm{O}\right)$ versus $\mathrm{SiO}_{2}(a, c$; both in wt \%; Le Bas et al. 1986) and normative Ne-Ol-Q ( $b, d$; Poldervaart 1966). In the western SKC, most Late Eocene-Oligocene lavas are within the alkali field, but some points straddle the dividing line, whereas the post-Miocene lavas are dominantly tholeiitic basalts with subordinate alkali basalts. However, the opposite trend is noted for Cenozoic basalts from the eastern SKC. Data for the eastern SKC basalts: E and Zhao (1987), Dostal et al. (1988, 1991), Chen et al. (1990), Fan and Hooper (1991), Liu et al. (1994), and Chung (1999).

both appear to be consistent with variable depth of melt segregation. If the degree of melting is the main factor, the samples with high $\mathrm{La} / \mathrm{Yb}$ ratios and low $\mathrm{Yb}$ contents are likely generated under a thick lithosphere because the degree of melting is inversely proportional to the lithospheric thickness (see discussion in "Methodology"). Accordingly, the different $\mathrm{La} / \mathrm{Yb}$ ratios and HREE contents in the Early Tertiary and Miocene-Quarternary basalts (fig. 3) are related to different lithospheric thicknesses. This conclusion holds if the variable $\mathrm{Cpx} / \mathrm{Gt}$ ratio is the controlling factor because in the upper mantle, this ratio increases with depth.
The Sr-Nd isotopic variation in the western SKC basalts (fig. 4) reflects that of mantle sources involved in basaltic genesis because the presence of mantle xenoliths and oceanic island basalt (OIB)like $\mathrm{Nb} / \mathrm{La}$ and $\mathrm{U} / \mathrm{Nb}$ ratios preclude significant crustal contamination. Although the isotopic range in the Cenozoic basalts overlaps that of the mantle xenoliths (fig. 5), the melting of the mantle similar to that of xenoliths (lithospheric mantle) is not a viable mechanism to generate the Cenozoic basalts from the SKC. This is because of the following three reasons: (1) Sm-Nd model ages (Song and Frey 1989) and Re-Os isotopes (Gao et al. 2002) suggest 
Table 2. Representative Analyses of Cenozoic Basalts from the Shanxi Graben, Western Sino-Korean Craton

\begin{tabular}{|c|c|c|c|c|c|c|c|c|c|c|c|c|c|c|}
\hline & \multicolumn{3}{|c|}{ Datong $(<1 \mathrm{Ma})$} & \multicolumn{3}{|c|}{ Fengzhen (7-14 Ma) } & \multicolumn{3}{|c|}{ Yangyuan (15-30 Ma) } & \multicolumn{2}{|c|}{ Yinxian (38-40 Ma) } & \multicolumn{3}{|c|}{ Fanshi $(38-40 \mathrm{Ma})$} \\
\hline & $\begin{array}{l}\text { DT-10 } \\
\text { (Q-Th) }\end{array}$ & $\begin{array}{l}\text { DT-19 } \\
\text { (Tran) }\end{array}$ & $\begin{array}{l}\text { DT-22 } \\
\text { (AOB) }\end{array}$ & $\begin{array}{c}\text { FZ-4 } \\
\text { (Q-Th) }\end{array}$ & $\begin{array}{l}\text { YSZ-1 } \\
\text { (Q-Th) }\end{array}$ & $\begin{array}{l}\text { YSZ-8 } \\
\text { (AOB) }\end{array}$ & $\begin{array}{l}\text { YY-4 } \\
\text { (AB) }\end{array}$ & $\begin{array}{l}\text { YY-7 } \\
\text { (AB) }\end{array}$ & $\begin{array}{c}\text { YY-8 } \\
\text { (AOB) }\end{array}$ & $\begin{array}{l}\text { HHL-8 } \\
\text { (AOB) }\end{array}$ & $\begin{array}{c}\text { HHL-11 } \\
(\mathrm{AB})\end{array}$ & $\begin{array}{c}\text { TXG-6 } \\
\text { (AB) }\end{array}$ & $\begin{array}{c}\text { TXG-10 } \\
\text { (AB) }\end{array}$ & $\begin{array}{c}\text { TXGB-5 } \\
\text { (AB) }\end{array}$ \\
\hline $\bar{Q}$ & 7.8 & 1.5 & 0 & 4.3 & 5.9 & 0 & 0 & 0 & 0 & 0 & 0 & 0 & 0 & 0 \\
\hline $\mathrm{Ne}$ & 0 & 0 & 0 & 0 & 0 & 0 & 9.7 & 11.7 & 0 & 0 & 3.3 & 6.9 & 1.2 & 7.4 \\
\hline $\mathrm{Ol}$ & 0 & 0 & 6.6 & 0 & 0 & 5.3 & 12.3 & 12.0 & 6.2 & 11.5 & 15.2 & 16.5 & 18.7 & 17.6 \\
\hline Hy & 21.1 & 18.0 & 9.9 & 14.8 & 17.3 & 9.3 & 0 & 0 & 5.6 & 7.9 & 0 & 0 & 0 & 0 \\
\hline $\mathrm{SiO}_{2}$ & 55.06 & 52.65 & 50.5 & 52.67 & 52.73 & 49.14 & 46.18 & 45.76 & 48.94 & 48.34 & 44.77 & 43.35 & 46.81 & 43.67 \\
\hline $\mathrm{TiO}_{2}$ & 1.71 & 2.22 & 2.36 & 2.39 & 2.22 & 2.99 & 2.69 & 2.70 & 2.06 & 1.85 & 2.45 & 2.72 & 1.95 & 2.56 \\
\hline $\mathrm{Al}_{2} \mathrm{O}_{3}$ & 13.16 & 13.12 & 13.75 & 13.08 & 13.40 & 12.79 & 14.38 & 14.38 & 14.90 & 14.48 & 13.71 & 14.70 & 14.70 & 14.83 \\
\hline $\mathrm{Fe}_{2} \mathrm{O}_{3}$ & 11.99 & 12.78 & 13.34 & 12.24 & 12.21 & 13.57 & 13.44 & 13.52 & 12.05 & 13.69 & 13.35 & 13.21 & 13.32 & 13.22 \\
\hline $\mathrm{MgO}$ & 7.30 & 6.49 & 6.72 & 6.25 & 6.77 & 6.99 & 6.65 & 6.64 & 5.96 & 7.79 & 8.59 & 8.88 & 9.26 & 9.67 \\
\hline $\mathrm{MnO}$ & .15 & .16 & .17 & .14 & .14 & .15 & .15 & .15 & .13 & .15 & .17 & .17 & .17 & .19 \\
\hline $\mathrm{CaO}$ & 7.73 & 7.10 & 7.30 & 7.89 & 8.34 & 7.56 & 7.26 & 7.32 & 9.29 & 8.56 & 9.54 & 8.13 & 9.11 & 8.99 \\
\hline $\mathrm{Na}_{2} \mathrm{O}$ & 3.03 & 3.80 & 3.88 & 3.23 & 2.92 & 3.41 & 5.43 & 5.64 & 3.35 & 3.20 & 3.36 & 4.02 & 2.93 & 3.66 \\
\hline $\mathrm{P}_{2} \mathrm{O}_{5}$ & .19 & .57 & .63 & .41 & .37 & .80 & 1.09 & 1.08 & .38 & .28 & .80 & .72 & .33 & .68 \\
\hline $\begin{array}{l}2 \\
\mathrm{~K}_{2} \mathrm{O}\end{array}$ & .52 & 1.46 & 1.60 & 1.45 & .89 & 2.11 & 1.46 & 1.47 & 1.36 & .93 & 1.03 & 1.04 & 1.31 & 1.16 \\
\hline LOI & .80 & .36 & .56 & .18 & .06 & .45 & 1.02 & 1.09 & 1.59 & .66 & 1.98 & 2.85 & .13 & 1.33 \\
\hline Total & 100.02 & 99.98 & 99.70 & 99.93 & 99.93 & 99.94 & 999.78 & 99.76 & 100.00 & 99.95 & 99.76 & 99.78 & 99.77 & 99.95 \\
\hline $\mathrm{Cr}$ & 244.7 & 202.9 & 197.1 & 188.9 & 195.6 & 125.9 & 150.2 & 140.3 & 272 . & 247.9 & 193.8 & 134.1 & 257.8 & 142.5 \\
\hline $\mathrm{Ni}$ & 137.1 & 142.6 & 137.5 & 105.4 & 131.3 & 139.6 & 118.7 & 114.3 & 117.9 & 165.4 & 147.0 & 155.8 & 168.7 & 185.9 \\
\hline $\mathrm{Rb}$ & 8.42 & 24.78 & 26.91 & 20.65 & 11.56 & 30.08 & 60.15 & 75.24 & 11.67 & 10.17 & 33.76 & 5.68 & 13.18 & 10.33 \\
\hline $\mathrm{Sr}$ & 277. & 632. & 708. & 459. & 445. & 835. & 1185 . & 1175 . & 591. & 428 & 793. & 886. & 537. & 1132. \\
\hline Y & 23.84 & 28.63 & 29.09 & 25.12 & 21.12 & 23.71 & 22.73 & 23.01 & 19.65 & 21.04 & 21.91 & 20.69 & 20.25 & 24.38 \\
\hline $\mathrm{Zr}$ & 110.5 & 259.4 & 269. & 179.3 & 154.1 & 291.7 & 376.7 & 375.2 & 147.7 & 131.9 & 214 . & 295.3 & 149.9 & 278.1 \\
\hline $\mathrm{Nb}$ & 10.08 & 42.52 & 45.68 & 29.24 & 23.21 & 57.72 & 85.63 & 84.37 & 26.55 & 13.41 & 43.78 & 56.67 & 21.07 & 58.75 \\
\hline $\mathrm{Ba}$ & 157.2 & 348.4 & 378.2 & 294.5 & 278.5 & 473.1 & 589.9 & 601.6 & 271. & 306.7 & 741.4 & 445 . & 368.5 & 509. \\
\hline $\mathrm{La}$ & 9.38 & 29.24 & 31.23 & 19.7 & 16.32 & 34.33 & 53.66 & 53.97 & 17.71 & 14.81 & 33.43 & 38.74 & 18.29 & 42.06 \\
\hline $\mathrm{Ce}$ & 20.23 & 58.57 & 63.14 & 39.96 & 35.61 & 70.14 & 106.10 & 106.40 & 36.34 & 31.52 & 71.97 & 75.87 & 39.14 & 81.04 \\
\hline Pr & 2.79 & 7.40 & 7.99 & 5.30 & 4.82 & 9.29 & 13.58 & 13.41 & 4.84 & 4.41 & 9.52 & 9.48 & 5.15 & 9.85 \\
\hline $\mathrm{Nd}$ & 13.17 & 31.26 & 32.95 & 22.75 & 21.84 & 39.06 & 55.50 & 55.41 & 21.15 & 19.02 & 39.28 & 39.60 & 22.19 & 39.82 \\
\hline Sm & 3.96 & $\begin{array}{l}7.24 \\
\end{array}$ & 7.63 & 5.77 & 5.37 & 8.83 & 11.14 & $\begin{array}{l}11.33 \\
11.33\end{array}$ & 5.24 & 4.51 & $\begin{array}{l}7.66 \\
\end{array}$ & 8.02 & 4.86 & 7.52 \\
\hline $\mathrm{Eu}$ & 1.51 & 2.51 & 2.55 & 1.98 & 1.88 & 2.89 & 3.59 & 3.57 & 1.82 & 1.58 & 2.43 & 2.56 & 1.61 & 2.35 \\
\hline $\mathrm{Gd}$ & 5.31 & 7.84 & 7.83 & 6.56 & 5.85 & 8.38 & 9.71 & 9.51 & 5.56 & 5.08 & 6.83 & 7.19 & 5.38 & 7.04 \\
\hline $\mathrm{Tb}$ & .86 & 1.14 & 1.17 & .98 & .86 & $\begin{array}{l}1.00 \\
1.12\end{array}$ & 1.22 & 1.24 & .80 & .77 & .91 & 1.00 & .77 & .99 \\
\hline Dy & 4.78 & 6.10 & 6.21 & 5.37 & 4.59 & 5.57 & 5.84 & 5.83 & 4.20 & 4.24 & 4.79 & 4.82 & 4.24 & 5.10 \\
\hline Ho & .90 & 1.09 & 1.11 & .97 & .81 & .91 & .88 & .89 & .75 & .80 & .84 & .77 & .76 & .88 \\
\hline Er & 2.29 & 2.65 & 2.65 & 2.34 & 1.95 & 2.03 & 1.88 & 1.90 & 1.80 & 2.02 & 2.05 & 1.91 & 2.13 & 2.39 \\
\hline Tm & .33 & .38 & .37 & .34 & .27 & .25 & .21 & .22 & .25 & .29 & .28 & .24 & .30 & .32 \\
\hline $\mathrm{Yb}$ & 2.07 & 2.19 & 2.20 & 2.01 & 1.63 & 1.44 & 1.17 & 1.17 & 1.49 & 1.81 & 1.67 & 1.41 & 1.87 & 1.90 \\
\hline $\mathrm{Lu}$ & .30 & .32 & .33 & .30 & .24 & .20 & .15 & .16 & .22 & .28 & .25 & .20 & .28 & .29 \\
\hline $\mathrm{Hf}$ & 3.16 & 6.20 & 6.46 & 4.58 & 3.95 & 6.79 & 8.45 & 8.49 & 3.62 & 3.25 & 4.67 & 6.45 & 3.61 & 5.95 \\
\hline $\mathrm{Ta}$ & .64 & 2.67 & 2.90 & 1.80 & 1.42 & 3.64 & 5.43 & 5.40 & 1.63 & .87 & 2.60 & 3.31 & 1.19 & 3.32 \\
\hline $\mathrm{Pb}$ & 3.49 & 3.83 & 2.57 & 3.36 & 3.39 & 3.37 & 4.50 & 4.58 & 1.65 & 2.34 & 3.53 & 3.02 & 2.88 & 3.46 \\
\hline Th & 1.03 & 3.82 & 4.10 & 2.25 & 1.64 & 3.98 & 6.63 & 6.63 & 1.80 & 1.17 & 3.26 & 3.70 & 1.65 & 4.23 \\
\hline U & .28 & $\begin{array}{r}.02 \\
.96\end{array}$ & .94 & .66 & .41 & $\begin{array}{l}1.09 \\
1.09\end{array}$ & $\begin{array}{l}1.74 \\
1.74\end{array}$ & 1.74 & .46 & 32 & .87 & 1.23 & .45 & 1.20 \\
\hline $\mathrm{Nb} / \mathrm{La}$ & 1.1 & 1.5 & 1.5 & 1.5 & 1.4 & 1.7 & 1.6 & 1.6 & 1.5 & .9 & 1.3 & 1.5 & 1.2 & 1.4 \\
\hline $\mathrm{La} / \mathrm{Yb}$ & 4.5 & 13.3 & 14.2 & 9.8 & 10.0 & 23.8 & 45.8 & 46.3 & 11.9 & 8.2 & 20.0 & 27.6 & 9.8 & 22.1 \\
\hline 年 & .704393 & .703650 & .704170 & .704940 & .704692 & .703822 & .703805 & .703788 & .704716 & .704615 & .704000 & .703768 & .704947 & .705085 \\
\hline$\left({ }^{87} \mathrm{Sr} /{ }^{866} \mathrm{Sr}\right)_{i}$ & .704393 & .703650 & .704169 & .704922 & .704681 & .703808 & .703742 & .703709 & .704692 & .704576 & .703932 & .703757 & .704907 & .705070 \\
\hline${ }^{143} \mathrm{Nd} /{ }^{144} \mathrm{Nd}$ & .512723 & .512939 & .512958 & .512698 & .512783 & .512930 & .512924 & .512909 & .512746 & .512460 & .512760 & .512843 & .512513 & .512725 \\
\hline$\varepsilon_{N d}(t)^{\prime}$ & 1.66 & 5.87 & 6.24 & 1.42 & 3.08 & 5.95 & 6.34 & 6.05 & 2.87 & -2.48 & 3.38 & 4.99 & -1.44 & 2.69 \\
\hline
\end{tabular}

Note. The whole-rock major and trace element compositions were obtained using inductively coupled plasma mass spectrometry (ICP-MS) and ICP-AES at the Guangzhou Institute of Geochemistry, Chinese Academy of Sciences (GIGCAS). Precision is better than 1 for major elements, $5 \%$ for REE, and 5\%-10\% for other incompatible elements. Sr-Nd isotopic ratios have been measured using

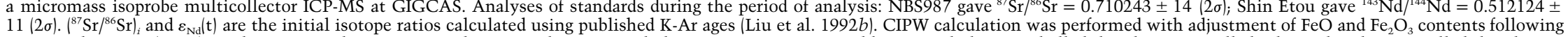
Irvine and Baragar (1971). Rock types are shown in parentheses. Q-Th $=$ quartz tholeiite; Tran $=$ transitional between tholeiite and alkali basalt; $\mathrm{AOB}=$ alkali olivine basalt; $\mathrm{AB}=$ alkali basalt. 


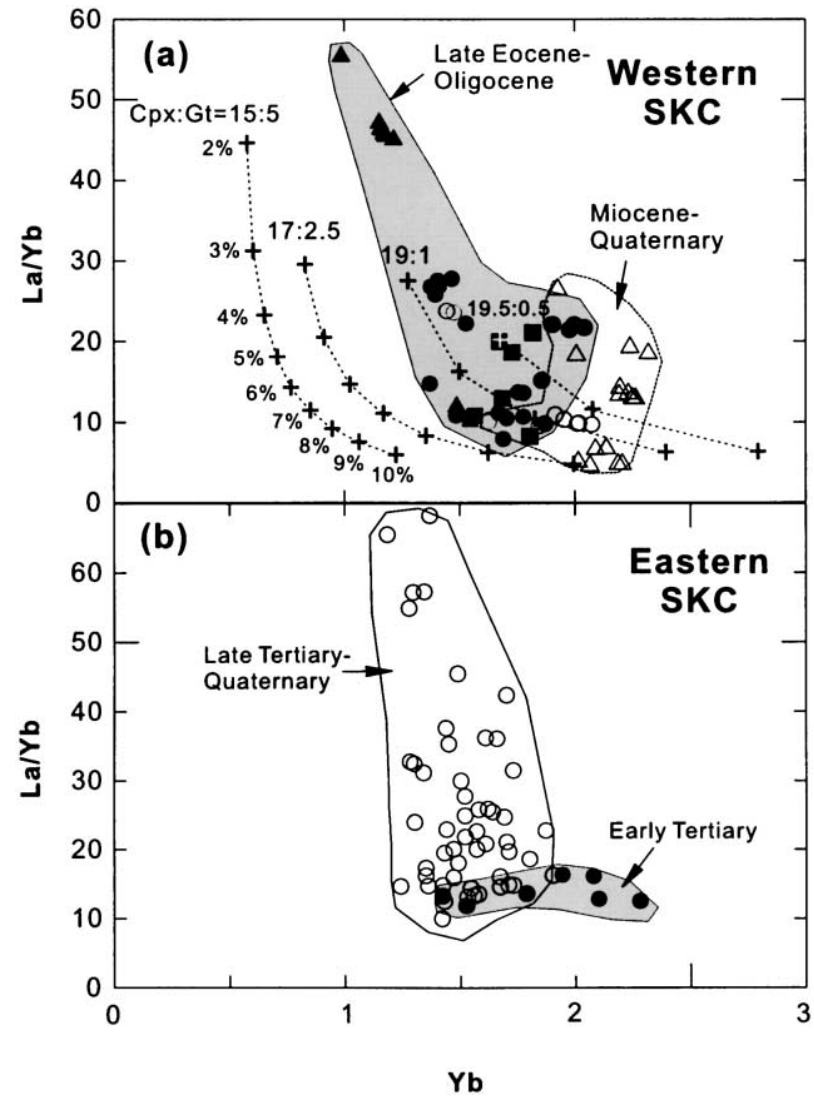

Figure 3. Plots of $\mathrm{La} / \mathrm{Yb}$ versus $\mathrm{Yb}$. Data sources for basalts from the eastern SKC: Fan and Hooper (1991), Dostal et al. (1988, 1991), Chen et al. (1990), Liu et al. (1994), and Chung (1999). Symbols are as in figure $2 a$. Partial melting lines are calculated using the batch melting model of Shaw (1970) with different clinopyroxene/ garnet $(\mathrm{Cpx} / \mathrm{Gt})$ ratios in residual mineralogy (olivine $60 \%$; orthopyroxene $20 \%$ ). The source composition is that of an enriched lherzolite xenolith from Yangyuan with $0.72 \mathrm{ppm} \mathrm{La}$ and $0.2 \mathrm{ppm}$ Yb (Y.-G. Xu, J. L. Ma, F. A. Frey, M. D. Feigenson, and J. F. Liu, unpub. data). A constant melting mode of Gt $(40 \%)$ and Cpx (40\%) was assumed. Numbers mark the degree of partial melting. Partition coefficients are from those of Johnson (1998).

that the mantle lithosphere beneath the western SKC was subjected to melting during the Proterozoic. This considerably predates the Cenozoic melting events. (2) Most of the studied basalts display OIB-like trace element compositions, implying an enriched mantle source. In contrast, mantle xenoliths are either LREE depleted or LREE enriched. Furthermore, some enriched xenoliths are depleted in $\mathrm{Nb}$ and $\mathrm{Ta}$ and therefore cannot be the source of OIB-like basalts. (3) In general, the lithospheric mantle is too cold to melt. The thermomechanical model suggests that only a small amount of melt can be produced from the lithospheric mantle by conduction of heat from a mantle plume (McKenzie and Bickle 1988; Arndt and Christensen 1992). Generation of intraplate basalts is likely confined to the convective asthenosphere or plume.

An asthenospheric origin of the Cenozoic basalts in the western SKC is supported by the fact that all samples have positive $\mathrm{Nb}$ and $\mathrm{Ta}$ anomalies, with $\mathrm{Nb} / \mathrm{La}(1.1-1.5)$ within the range of OIB (Sun and McDonough 1989; table 2). Although the analyzed samples display a range of $\mathrm{Sr}$ and $\mathrm{Nd}$ isotopic ratios $\left(\left({ }^{87} \mathrm{Sr} /{ }^{86} \mathrm{Sr}\right)_{i}=0.7036-0.7051\right.$ and $\varepsilon_{\mathrm{Nd}}(\mathrm{t})=$ $+6.3--2.51$, there is no systematic difference between the Early Tertiary and the Miocene-Quaternary magmas. For instance, all but one sample from Yangyuan (Early Tertiary) show a homogeneous Sr$\mathrm{Nd}$ isotopic composition with $\left({ }^{87} \mathrm{Sr} /{ }^{86} \mathrm{Sr}\right)_{i}$ ranging from 0.70371 to 0.70374 and $\varepsilon_{\mathrm{Nd}}(\mathrm{t})$ of $+6.0-6.3$, despite an $\mathrm{SiO}_{2}$ range of $48 \%-52 \%$. Similar isotopic ratios are observed in some Miocene-Quaternary basalts from Datong, Fengzhen, and Hannuoba (Song et al. 1990; Basu et al. 1991; table 1). This suggests that the Cenozoic lavas share a common end member (i.e., the asthenosphere).

Lavas from individual localities, except Fanshi, define roughly negative correlations in $\mathrm{Sr}-\mathrm{Nd}$ isotopic space (fig. 4). Specifically, tholeiites generally have lower $\varepsilon_{\mathrm{Nd}}(\mathrm{t})$ and higher $\left({ }^{87} \mathrm{Sr} /{ }^{86} \mathrm{Sr}\right)_{i}$ than alkali olivine basalts. This isotopic variation may have

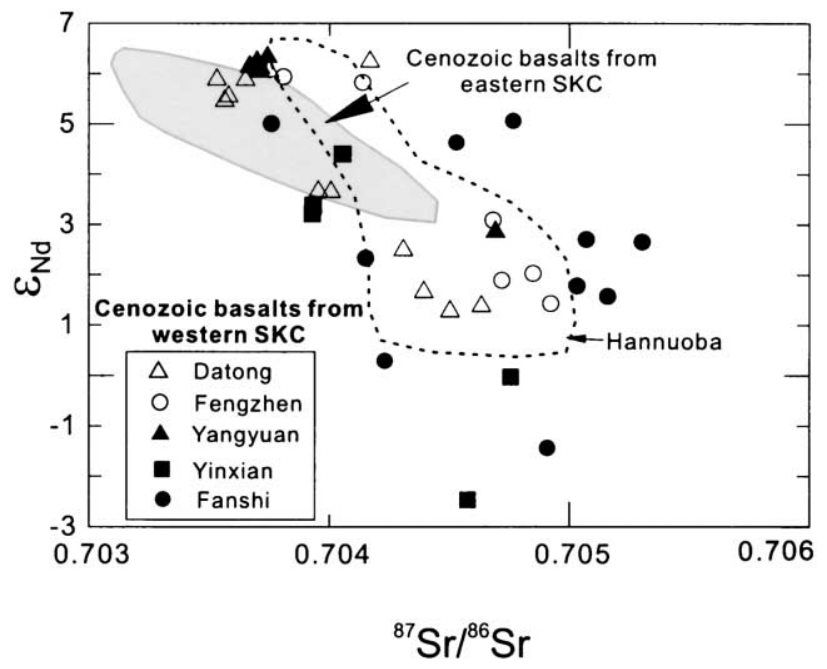

Figure 4. $\quad{ }^{143} \mathrm{Nd} /{ }^{144} \mathrm{Nd}$ versus ${ }^{87} \mathrm{Sr} /{ }^{86} \mathrm{Sr}$ of the Cenozoic basalts from the western SKC. Symbols are the same as in figure $2 a$. The field for Cenozoic basalts from the Shandong and Bohai areas in the eastern SKC is outlined, based on data from Zhou and Armstrong (1982), Peng et al. (1986), Basu et al. (1991), and Liu et al. (1995). 


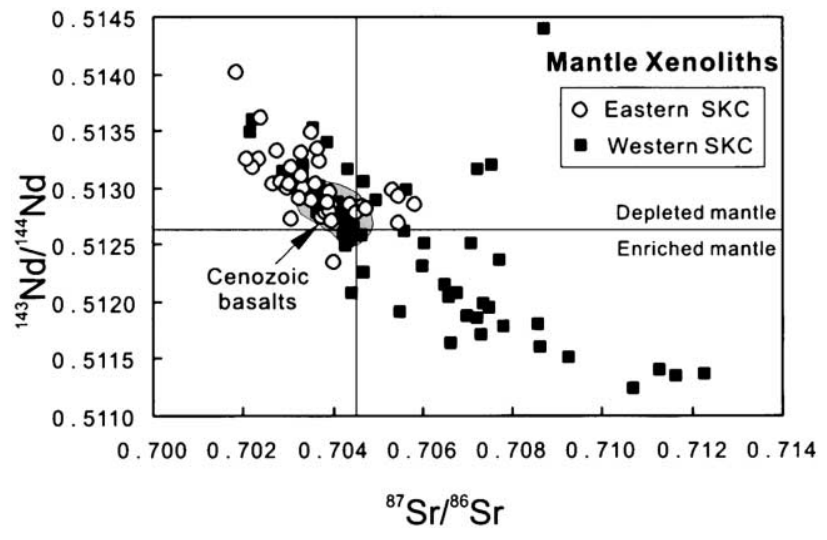

Figure 5. Variation of ${ }^{143} \mathrm{Nd} /{ }^{144} \mathrm{Nd}$ versus ${ }^{87} \mathrm{Sr} /{ }^{86} \mathrm{Sr}$ of mantle xenoliths in Cenozoic basalts from the SKC. Data sources for xenoliths: Song and Frey (1989), Tatsumoto et al. (1992), Xu et al. (1998, unpub. data), Fan et al. (2000), and $\mathrm{Xu}$ (2002). The field for Cenozoic basalts is outlined according to Zhou and Armstrong (1982), Peng et al. (1986), Basu et al. (1991), Liu et al. (1995), and this study.

resulted from interaction between the asthenosphere and lithospheric mantle (Song et al. 1990; Basu et al. 1991; Y.-G. Xu, J. L. Ma, F. A. Frey, M. D. Feigenson, and J. F. Liu, unpub. data). There is no significant correlation between $\varepsilon_{\mathrm{Nd}}(\mathrm{t})$ and $\mathrm{La} / \mathrm{Yb}$. For example, for samples with relatively low La/ $\mathrm{Yb}(<15)$, their $\varepsilon_{\mathrm{Nd}}(\mathrm{t})$ range from -2.5 to +6 (table 2). It seems that the lithosphere-asthenosphere interaction, if any, did not significantly modify the $\mathrm{La} / \mathrm{Yb}$ ratio. Lack of Sr-Nd isotopic correlation in the Fanshi basalts may be related to surface alteration processes that affected the $\mathrm{Rb}$-Sr systematics because these samples are the oldest of all those studied. Also, there is no correlation between $\mathrm{Nb}$ (immobile element) and $\mathrm{Rb}$.

According to the rationale described in "Methodology," the temporal decrease in alkaline content (fig. 2) and $\mathrm{La} / \mathrm{Yb}$ (fig. 3) probably mirrors a progressive thinning of the lithosphere beneath the Shanxi graben during the Cenozoic. Compared with experimental data, the predominance of alkali basalts in Late Eocene time suggests a lithosphere thicker than $80 \mathrm{~km}$ at that time. This inference is consistent with the fact that some Ne-normative laves from Fanshi (e.g., TXG-10) have negative $\varepsilon_{\mathrm{Nd}}(\mathrm{t})$ (table 2; see also DePaolo and Daley 2000). Under such a thick lithosphere, the generation of basalts was largely confined to the garnet stability field; thus, the samples have relatively low $\mathrm{Yb}$ contents and high $\mathrm{La} / \mathrm{Yb}$ ratios (fig. $3 a$ ) because the HREE are buffered by residual garnet in the source. Extremely low HREE contents and strongly frac- tionated REE in the Yangyuan basalts further suggest a very low degree of partial melting. Relatively low $\varepsilon_{\text {Nd }}(t)$ values (+5 to -2.5$)$ in the pre-Miocene lavas, compared with those of the asthenospheric end member, may indicate significant involvement of SCLM components in basaltic generation, probably in a "plum pudding" fashion as envisaged by Perry et al. (1987) during lithospheric thinning. In contrast, predominant $\mathrm{SiO}_{2}$-saturated and oversaturated features observed in the Miocene-Quaternary basalts suggest a shallower depth (spinelgarnet stability field) of magma generation. This is consistent with relatively lower $\mathrm{La} / \mathrm{Yb}$ and higher $\mathrm{Yb}$ contents in these lavas. Specifically, the Quaternary lavas from Datong have higher $\mathrm{SiO}_{2}$ and HREE contents and $\mathrm{Na} / \mathrm{Ti}$ ratios compared with other samples at comparable $\mathrm{MgO}$. Modeling involving REE and $\mathrm{Na}$ /Ti for these lavas (Y.-G. Xu, J. L. Ma, F. A. Frey, M. D. Feigenson, and J. F. Liu, unpub. data) implies an upwelling of the asthenosphere to a depth of around $70 \mathrm{~km}$, that is, a locally very thinned lithosphere in the western SKC at the present time.

\section{Basaltic Evolution in the Eastern SKC from Lithospheric Thickening}

Data available for Cenozoic basalts in the eastern SKC show a temporal variation in petrochemistry generally opposite to that observed in the western SKC (fig. 2c, 2d). The Early Tertiary basalts, which occur voluminously in extensional basins, are mainly quartz- and olivine-normative tholeiites, with subordinate subalkali basalts (olivine basalts) and minor alkali basalts (Fan and Hooper 1991; Liu et al. 1992b). It has been documented that the eruption of tholeiitic basalt was concomitant with a peak period of lithospheric extension that created several basins (Ren et al. 2002). Although limited, available isotopic data show a predominant depleted mantle signature in the Eocene tholeiites (Zhou and Armstrong 1982; Peng et al. 1986; Xu 2001). This suggests that the asthenosphere was uplifted to a very shallow level, the lithosphere was probably $<60 \mathrm{~km}$ thick (Xu 2001), and there was a very high thermal gradient (Menzies and Xu 1998). Subalkaline rocks continued to occur but diminished in quantity in the Late Tertiary and Quaternary, while alkali and strongly alkali basalts (basanite and nephelinite) progressively became the dominant rock types (fig. 2c, 2d). As expected, the Miocene-Quaternary lavas generally have higher $\mathrm{La} / \mathrm{Yb}$ than the Eocene basalts (fig. $3 b$ ). Also, mantle xenoliths are only found in post-Miocene basalts and are absent in Eocene-Oligocene magmas (E and 
Zhao 1987). The trend of increasing alkalinity with time in Cenozoic basalts from the eastern SKC has been recognized by several authors (Zhou and Armstrong 1982; Fan and Hooper 1991; Xu et al. 1995; Xu 2001) and can be attributed to declining degrees of partial melting and increasing depth of the source region. Thermal decay since Miocene time had been observed in the Bohai basin $(\mathrm{Hu}$ et al. 2001), consistent with a weaker lithospheric extension during the Neogene than the Early Tertiary (Deng 1988). It is envisaged that upwelled asthenosphere converts thermally and rheologically to lithosphere as a response to decreasing temperature (Jordan 1988).

\section{Discussion and Conclusions}

Diachronous Lithospheric Extension in the Western and Eastern SKC. Basalt compositions are consistent with a dominant asthenospheric source for the Cenozoic basalts from both sides of the DTGL. However, there is marked temporal variation in depth and degree of mantle melting in the two regions. While basalts from the western SKC were generated by progressive lithospheric thinning, those from the eastern SKC likely reflect lithospheric thickening/accretion. Such contrasting lithospheric processes may be related to diachronous lithospheric extension in the SKC. In a recent review, Ren et al. (2002) showed that widespread continental rift systems and continental basins in the eastern SKC were mainly formed during the Late Cretaceous-Paleogene. These Early Tertiary basins then entered a postrifting phase during Neogene time, thus forming regional downwarping. The thermal subsidence is also revealed by thermal modeling in the Bohai area, which showed a decrease in heat flow from $75-90 \mathrm{~mW} / \mathrm{m}^{2}$ in the Early Miocene to $55-65 \mathrm{~mW} / \mathrm{m}^{2}$ nowadays (Hu et al. 2001). In the western SKC, although rifting started in the Hetao-Yinchuan graben system and the southern part of the Shanxi graben in the Early Oligocene or Late Eocene, major extension and rapid subsidence occurred in the Neogene and Quaternary (Ye et al. 1987); thus, a delayed extension in the western SKC relative to the eastern SKC is implied. In this context, a lithospheric thinning stage, similar to that observed in the Shanxi graben, should have occurred in the eastern SKC prior to the Cenozoic because Cenozoic basalts record only a state of lithospheric thickening/accretion. Such a lithospheric thinning stage has been proposed on the basis of the compositions of Mesozoic to Cenozoic basalts (Xu 2001). Late Mesozoic alkali basalts and intrusive mafic rocks in the Shandong
Province have low $\varepsilon_{\mathrm{Nd}}(\mathrm{t})(-10$ to -20$)$ and $\mathrm{Nb} / \mathrm{La}$ $(<0.5$; Guo et al. 2001; Zhang et al. 2002; Yang et al. 2004), in contrast with a positive $\varepsilon_{\mathrm{Nd}}(\mathrm{t})$ and high $\mathrm{Nb} / \mathrm{La}(>1)$ in the Early Tertiary tholeiites (Zhou and Armstrong 1982; Peng et al. 1986; Chung 1999). The transition from Cretaceous SCLM-derived alkali basalts to Paleogene asthenosphere-derived tholeiites in the eastern SKC may have resulted from the replacement of lithospheric keel by upwelling asthenosphere during the Late Cretaceous (Xu 2001; Xu et al. 2004).

Diachronous lithospheric extension in the western and eastern SKC may be related to interactions between different tectonic regimes. While the extension in the Shanxi graben was likely related to the Indo-Eurasian collision (Molnar and Tapponnier 1977), the north-northeast-trending basins in the eastern SKC may have been induced by subduction of the Pacific plate underneath the Asian continent, which began at the end of the Mesozoic (Ye et al. 1987). Nevertheless, the north-southtrending extension in some Late Mesozoic basins in the southern SKC (Ren et al. 2002) may reflect subduction of the Yangtze Block beneath the SKC.

Heterogeneous Lithospheric Composition and Structure beneath the SKC. An important implication of the diachronous lithospheric evolution is that lithospheric mantle beneath the eastern SKC is stratified with old lithosphere overlying newly accreted lithosphere, whereas the lithospheric mantle beneath the western SKC may consist mainly of old lithospheric relicts after thermomechanical erosion (fig. 6). This prediction is supported by isotopic data for mantle xenoliths, which are direct samples of the lithospheric mantle. As shown in figure 5, mantle xenoliths from the eastern SKC isotopically resemble oceanic basalts, in contrast to those from the western SKC that encompass both depleted and enriched mantle fields. Moreover, a recent Re-Os isotopic investigation reveals remarkably different stabilization ages for the lithospheric mantle beneath the eastern and western SKC (Gao et al. 2002). Although the peridotite xenoliths from Hannuoba (western SKC) define a Mesoproterozoic Re-Os isochron age of $1.9 \mathrm{Ga}$, the Qixia peridotites from the eastern SKC have modern $T_{\mathrm{RD}}$ and $T_{\mathrm{MA}}$ ages (Gao et al. 2002).

Heterogeneous lithospheric mantle composition beneath the SKC is also reflected by the different $\mathrm{Sr}-\mathrm{Nd}$ isotopic ranges of Cenozoic lavas from the western and eastern parts (fig. 4). Specifically, the western SKC lavas display a larger Sr-Nd isotopic range and tend to have lower $\varepsilon_{\mathrm{Nd}}$ than those from the eastern SKC (fig. 4). This is understandable within the lithosphere-asthenosphere interaction 


\section{Western SKC}

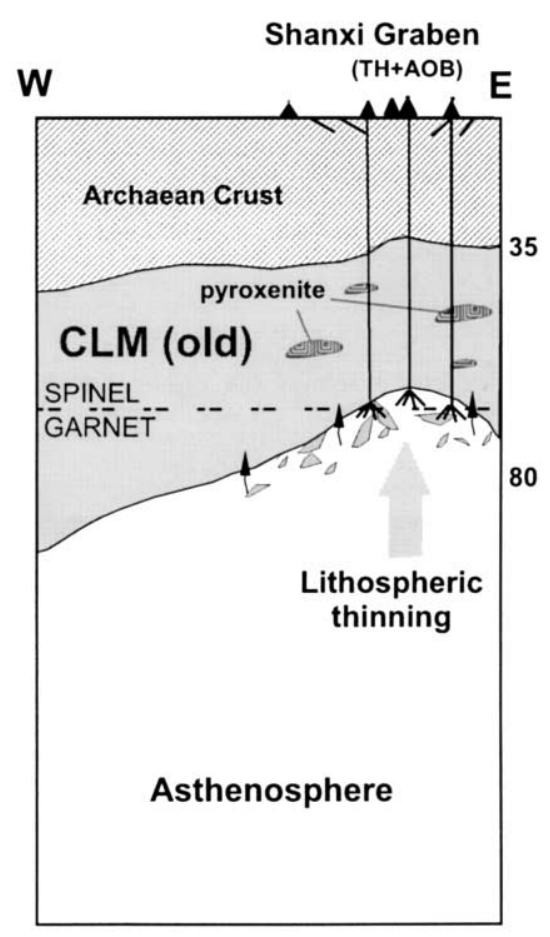

\section{Eastern SKC}

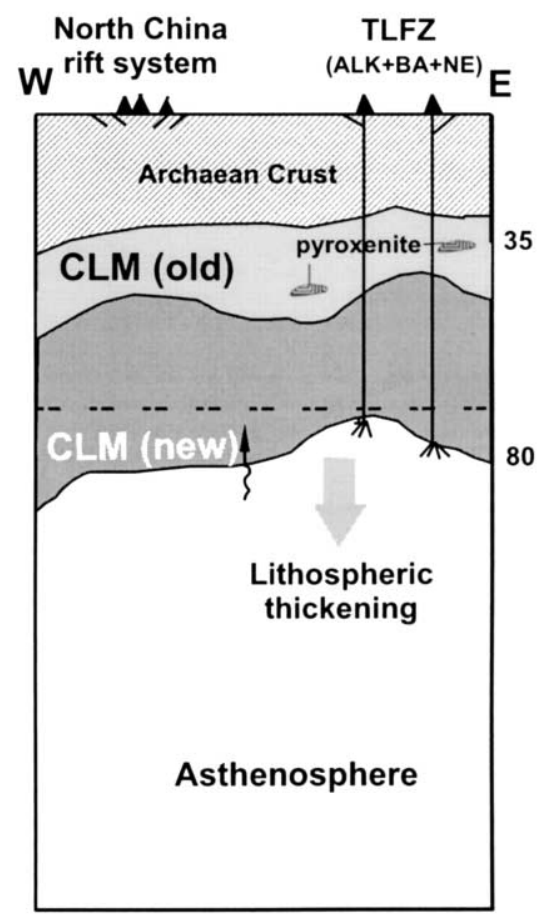

Figure 6. Schematic illustration of heterogeneous composition and structure of the present-day lithospheric mantle beneath the SKC. Left, Western SKC. The lithosphere is progressively thinned as a result of continuous upwelling of asthenosphere. The lithospheric mantle consists of old lithospheric relicts after thermomechanical erosion. Right, Eastern SKC. The lithosphere becomes progressively thickened through an asthenospheric accretion due to thermal loss. As a consequence, the lithospheric mantle is stratified with old lithosphere overlying newly accreted lithosphere.

scheme. In the western SKC, where Proterozoic lithospheric mantle is in contact with the convective asthenosphere (fig. 6, left), basalts partly inherit the enriched isotopic character of old SCLM. In contrast, in the eastern SKC, the lower lithospheric mantle accreted recently from the asthenosphere (fig. 6, right) and therefore has a depleted isotopic signature. So, even if lithosphereasthenosphere interaction were operative, the inherited asthenospheric signature of the newly accreted lithosphere would not cause any significant isotopic variation in the basalts formed. In summary, Sr-Nd isotopic compositions of Cenozoic basalts provide additional support for the contrasting composition of the lithospheric mantle beneath the western and eastern SKC.

Implication for the Mechanism of Lithospheric Destruction in the SKC. Lithospheric thinning in eastern China probably proceeded diachronously, with that in the eastern SKC occurring later than that in the western part. This diachronous lithospheric extension (or thinning) is most likely related to in- teractions of different tectonic regimes. There could, therefore, be multiple causes for the destabilization of the cratonic lithosphere beneath the SKC (Menzies et al. 1993; Griffin et al. 1998; Fan et al. 2000; Xu 2001); at least the lithospheric thinning in the western and eastern SKC should be considered separately. In the eastern SKC, the destruction of the lithospheric keel was probably related to a combined effect of (1) the Triassic collision between the North China and Yangtze Blocks and (2) the Mesozoic subduction of the Pacific plate underneath the Asian continent. The former may have destroyed the physical integrity of the lithosphere beneath the SKC, resulting in the formation and/or reactivation of major shear zones/strike-slip faults (Xu 2001) and east-west-trending Mesozoic extensional basins in the southern SKC (Ren et al. 2002). The latter governed the north-south-trending extensional basins (Ye et al. 1987). The influence of the western Pacific subduction in the western SKC must have been very limited because there 
is little evidence of faulting in the Eocene, and the Oligocene graben-type sediments are generally thin (Ye et al. 1987). Lithospheric thinning in the western SKC is most likely related to mantle flow and convection along the lithospheric weakness induced by the Indo-Eurasian collision (Molnar and Tapponnier 1977). The northeastward propagation of rifting and the stress patterns in the Shanxi graben can be accounted for by the east-northeastward movement of the Tibetan Plateau (Ye et al. 1987).

It is also important to note that Cenozoic rift systems in the SKC were developed along major translithospheric faults and/or boundaries between craton and fold belts. For instance, the North China rift system is bounded to the east by the Tanlu fault and to the west by the boundary between the central and eastern zones of the SKC (see the new tectonic subdivision of the SKC in Zhao et al. 2001). The Shanxi graben roughly coincides with the boundary between the central and western zones (fig. 1). Lithospheric extension and thinning therefore likely was initiated along these major structural-tectonic boundaries where the lithosphere was weakest and mantle flows became focused. Mantle flow could be further enhanced by thermal anomalies resulting from secondary convection induced by topographic differences between different blocks and lithospheric extension along lines of weakness (King and Anderson 1995). This requirement of topographic difference is met in the case of the SKC, where the thickness of lithospheric keel near the DTGL appears to be different (Menzies et al. 1993; Griffin et al. 1998). It is therefore possible that convective removal of the lithospheric keel beneath the SKC started along the lithospheric boundaries and faults and propagated toward the interior of the rigid lithosphere. The lithospheric thinning probably proceeded through heat transport into the lithosphere by small-scale asthenospheric convection induced by extension (Buck 1986). Once lithospheric mantle is thermally converted to asthenosphere, it can convectively mix with, and eventually be replaced by, asthenosphere. Progressive lithospheric thinning triggered further upwelling of asthenosphere, which may have led to widespread Cenozoic volcanism in the SKC.

\section{A C K N O W L E D G M E N T S}

We gratefully acknowledge the financial support of the National Natural Science Foundation of China (49925308) and the Chinese Academy of Sciences (the Baren Project). S.-S. Sun and an anonymous reviewer are thanked for their constructive criticism, which helped to improve the manuscript. F. Frey provided critical reading on the revised version. This article was completed while Y.-G. Xu was a visiting scientist at the National Taiwan University, which is supported by the National Science Council of Taiwan.

\section{R E F E R E N C E S C I T E D}

Arndt, N. T., and Christensen, U. 1992. The role of lithospheric mantle in continental flood volcanism: thermal and geochemical constraints. J. Geophys. Res. 97: 10,967-10,981.

Basu, A. R.; Wang, J. W.; Huang, W. K.; Xie, G. H.; and Tatsumoto, M. 1991. Major element, REE, and Pb, Nd, and $\mathrm{Sr}$ isotopic geochemistry of Cenozoic volcanic rocks of eastern China: implications for origin from suboceanic-type mantle reservoirs. Earth Planet. Sci. Lett. 105:149-169.

Buck, W. R. 1986. Small-scale convection induced by passive rifting: the cause for uplift of rift shoulders. Earth Planet. Sci. Lett. 77:362-372.

Chen, D. G.; Zhou, H. T.; Yang, J. D.; and Wang, Y. X. 1990. Isotopic evidence for petrogenesis of Cenozoic volcanic rocks and characteristics of mantle source from Shandong, Anhui, and Jiangsu. In Liu, R. X., ed. Characteristics and dynamics of the upper mantle in eastern China. Beijing, Seismologic Press, p. 124-131 (in Chinese).

Chung, S. L. 1999. Trace element and isotope characteristics of Cenozoic basalts around the Tanlu fault with implications for the eastern plate boundary between North and South China. J. Geol. 107:301-312.

Deng, J. F. 1988. Continental rift-related magmatism and deep processes. In Chi, J. S., ed. The study of Cenozoic basalts and the upper mantle beneath eastern China (attachment: kimberlites). Beijing, China University of Geoscience Press, p. 201-218 (in Chinese).

DePaolo, D. J., and Daley, E. E. 2000. Neodymium isotopes in basalts of the southwest basin and range and lithospheric thinning during continental extension. Chem. Geol. 169:157-185.

Dostal, J.; Dupuy, C.; Zhai, M.; and Zhi, X. 1988. Geochemistry and origin of Pliocene alkali basaltic lavas from Anhui-Jiangsu, eastern China. Geochem. J. 25: 165-176.

Dostal, J.; Zhi, X.; Muehlenbachs, K.; Dupuy, C.; and Zhai, M. 1991. Geochemistry of Cenozoic alkalic lavas from Shandong Province, eastern China. Geochem. J. 28:1-16.

E, M. L., and Zhao, D. S., eds. 1987. Cenozoic basalts and their deep-seated inclusions, eastern China. Beijing, Scientific Press, 490 p. (in Chinese). 
Ellam, R. M. 1992. Lithospheric thickness as a control on basalt geochemistry. Geology 20:153-156.

Falloon, T. J.; Green, D. H.; Harton, C. J.; and Harris, K. J. 1988. Anhydrous partial melting of a fertile and depleted peridotite from 2 to $30 \mathrm{~kb}$ and application to basalt petrogenesis. J. Petrol. 29:1257-1282.

Fan, Q., and Hooper, P. R. 1991. The Cenozoic basaltic rocks of eastern China: petrology and chemical composition. J. Petrol. 32:765-810.

Fan, W. M.; Zhang, H. F.; Baker, J.; Javis, K. E.; Mason, P. R. D.; and Menzies, M. A. 2000. On and off the North China craton: where is the Archean keel? J. Petrol. 41:933-950.

Fram, M. S., and Lesher, C. F. 1993. Geochemical constraints on mantle melting during creation of the North Atlantic basin. Nature 363:712-715.

Gallagher, K., and Hawkesworth, C. J. 1992. Dehydration melting and the generation of continental flood basalts. Nature 358:57-59.

Gao, S.; Rudnick, R. L.; Carlson, R. W.; McDonough, W. F.; and Liu, Y. S. 2002. Re-Os evidence for replacement of ancient mantle lithosphere beneath the North China craton. Earth Planet. Sci. Lett. 198:307-322.

Griffin, W. L.; Zhang, A. D.; O'Reilly, S. Y.; and Ryan, G. 1998. Phanerozoic evolution of the lithosphere beneath the Sino-Korean craton. In Flower, M.; Chung, S. L.; Lo, C. H.; and Lee, T. Y., eds. Mantle dynamics and plate interactions in East Asia. Am. Geophys. Union Geodyn. Ser. 27:107-126.

Guo, F.; Fan, W. M.; Wang, Y. J.; and Lin, G. 2001. Late Mesozoic mafic intrusive complexes in the North China block: constraints on the nature of subcontinental lithospheric mantle. Phys. Chem. Earth A 26: 759-771.

Hu, S. B.; O’Sullivan, P. B.; Raza, A.; and Kohn, B. P. 2001. Thermal history and tectonic subsidence of the Bohai Basin, northern China: a Cenozoic rifted and local pull-apart basin. Phys. Earth Planet. Inter. 126:221235.

Irvine, T. N., and Baragar, W. R. A. 1971. A guide to the chemical classification of common volcanic rocks. Can. J. Earth Sci. 8:523-548.

Jahn, B. M.; Auvray, B.; Cornichet, J. ; Bai, Y. L.; Shenk Q. H.; and Liu, D. Y. 1987. 3.5 Ga old amphibolites from eastern Hebei Province China: field occurrence, petrography, Sm-Nd isochron age, and REE geochemistry. Precambrian Res. 34:311-346.

Johnson, K. T. M. 1998. Experimental determination of partition coefficients for rare earth and high-fieldstrength elements between clinopyroxene, garnet, and basaltic melt at high pressures. Contrib. Mineral. Petrol. 133:60-68.

Jordan, T. H. 1988. Structure and formation of the continental tectosphere. J. Petrol., Special Lithosphere Issue, p. 11-37.

Kerr, A. C. 1994. Lithospheric thinning during the evolution of continental large igneous provinces: a case study from the North Atlantic Tertiary province. Geology 22:1027-1030.

King, S. D., and Anderson, D. L. 1995. An alternative mechanism of flood basalt formation. Earth Planet. Sci. Lett. 136:269-279.

Langmuir, C. H.; Klein, E. M.; and Plank, T. 1992. Petrological systematics of mid-ocean ridge basalts: constraints on melt generation beneath ocean ridges. In Morgan, J. P.; Blackman, D. K.; and Sinton, J. M., eds. Mantle flow and melt generation at mid-ocean ridges. Am. Geophys. Union Geophys. Monogr. 71:181-180.

Le Bas, M.; Le Maitre, R. W.; Strekeisen, A.; and Zanettin, B. 1986. A chemical classification of volcanic rocks based on the total alkali-silica diagram. J. Petrol. 27: 745-750.

Leeman, W. P., and Harry, D. L. 1993. A binary source model for extension-related magmatism in the Great Basin, western North America. Science 262:15501554.

Liu, C. Q.; Masuda, A.; and Xie, G. H. 1994. Major- and trace-element compositions of Cenozoic basalts in eastern China: petrogenesis and mantle source. Chem. Geol. 114:19-42.

Liu, C. Q.; Xie, G. H.; and Masuda, A. 1995. Geochemistry of Cenozoic basalts from eastern China (II): Sr, $\mathrm{Nd}$, and Ce isotopic compositions. Geochimica 24: 203-214 (in Chinese with English abstract).

Liu, D. Y.; Nutman, A. P.; Compston, W.; Wu, J. S.; and Shen, Q. H. 1992a. Remnants of 3800 Ma crust in the Chinese part of the Sino-Korean craton. Geology 20: 339-342.

Liu, R. X.; Chen, W. J.; Sun, J. Z.; and Li, D. M. $1992 b$. The K-Ar age and tectonic environment of Cenozoic volcanic rock in china. In Liu, R. X., ed. The age and geochemistry of Cenozoic volcanic rock in China. Beijing, Seismologic Press, p. 1-43 (in Chinese).

Lu, F. X.; Zhao, L.; Deng, J. F.; and Zheng, J. P. 1995. The discussion on the ages of kimberlitic magmatic activity in North China platform. Acta Petrol. Sinica 11: 365-374 (in Chinese with English abstract).

Ma, X., ed. 1989. Atlas of active faults in China. Beijing, Seismologic Press, 120 pp.

McKenzie, D. P., and Bickle, M. J. 1988. The volume and composition of melt generated by extension of the lithosphere. J. Petrol. 29:625-679.

Menzies, M. A. 1990. Archean, Proterozoic, and Phanerozoic lithospheres. In Menzies, M. A., ed. Continental mantle. Oxford, Clarendon, p. 67-86.

Menzies, M. A.; Fan, W. M.; and Zhang, M. 1993. Paleozoic and Cenozoic lithoprobes and the loss of $>120$ $\mathrm{km}$ of Archean lithosphere, Sino-Korean craton, China. In Prichard, H. M.; Alabaster, T.; Harris, N. B. W.; and Neary, C. R., eds. Magmatic processes and plate tectonics. Geol. Soc. Lond. Spec. Publ. 76:71-78.

Menzies, M. A., and Xu, Y. G. 1998. Geodynamics of the North China craton. In Flower, M.; Chung, S. L.; Lo, C. H.; and Lee, T. Y., eds. Mantle dynamics and plate interactions in East Asia. Am. Geophys. Union Geodyn. Ser. 27:155-165.

Molnar, P., and Tapponnier, P. 1977. Relation of the tectonics of eastern China to the India-Eurasian collision: application of slip-line field theory to large-scale continental tectonics. Geology 5:212-216. 
Nohda, S.; Chen, H.; and Tastumi, Y. 1991. Geochemical stratification in the upper mantle beneath NE China. Geophys. Res. Lett. 18:97-100.

Peng, Z. C.; Zartman, R. E.; Futa, E.; and Chen, D. G. 1986. Pb-, Sr-, and Nd-isotopic systematics and chemical characteristics of Cenozoic basalts, eastern China. Chem. Geol. 59:3-33.

Perry, F. V.; Baldridge, W. S.; and DePaolo, D. J. 1987. Role of asthenosphere and lithosphere in the genesis of Late Cenozoic basaltic rocks from the Rio Grande rift and adjacent regions of the southwestern United States. J. Geophys. Res. 92:9193-9213.

Poldervaart, A. 1966. Chemical definition of alkali basalts and tholeiites. Bull. Geol. Soc. Am. 74:229-232.

Ren, J.; Tamaki, K.; Li, S.; and Zhang, J. 2002. Late Mesozoic and Cenozoic rifting and its dynamic setting in eastern China and adjacent areas. Tectonophysics 344:175-205.

Shaw, D. M. 1970. Trace element fractionation during anatexis. Geochim. Cosmochim. Acta 34:237-243.

Song, Y., and Frey, F. A. 1989. Geochemistry of peridotite xenoliths in basalt from Hannuoba, eastern China: implications for subcontinental mantle heterogeneity. Geochim. Cosmochim. Acta 53:97-113.

Song, Y.; Frey, F. A.; and Zhi, X. 1990. Isotopic characteristics of Hannuoba basalts, eastern China: implications for their petrogenesis and the composition of subcontinental mantle. Chem. Geol. 88:35-52.

Sun, S.-S., and McDonough, W. F. 1989. Chemical and isotopic systematics of oceanic basalts: implications for mantle composition and processes. In Saunders, A. D., and Norry, M. J., eds. Magmatism in the ocean basins. Geol. Soc. Spec. Publ. 42:313-345.

Tatsumoto, M.; Basu, A. R.; Huang, W. K.; Wang, J. W.; and Xie, G. H. 1992. Sr, $\mathrm{Nd}$, and $\mathrm{Pb}$ isotopes of ultramafic xenoliths in volcanic rocks of eastern China: enriched components EMI and EMII in subcontinental lithosphere. Earth Planet. Sci. Lett. 113:107-128.

Wang, K.; Plank, T.; Walker, J. D.; and Smith, E. I. 2002. A mantle melting profile across the basin and range, SW USA. J. Geophys. Res. 107:B1, 2017, 10,1029/ 2001JB000209.

Xu, Y.-G. 2001. Thermotectonic destruction of the Archean lithospheric keel beneath eastern China: evidence, timing, and mechanism. Phys. Chem. Earth A 26:747-757.

. 2002. Evidence for crustal components in the mantle and constraints on crustal recycling mechanisms: pyroxenite xenoliths from Hannuoba, North China. Chem. Geol. 182:301-322.

Xu, Y.-G.; Fan, W. M.; and Lin, G. 1995. Lithosphereasthenosphere interaction: a comparative study on Cenozoic and Mesozoic basalts around Bohai area. Geotecton. Metallogen. 19:1-13.

Xu, Y.-G.; Huang, X. L.; Ma, J. L.; Wang, Y. B.; Iizuka, Y.; Xu, J. F.; Wang, Q.; and Wu, X. Y. 2004. Crustal-mantle interaction during the thermotectonic reactivation of the North China craton: SHRIMP zircon U-Pb age, petrology, and geochemistry of Mesozoic plutons in western Shandong. Contrib Mineral. Petrol., in press.

Xu, Y.-G.; Menzies, M. A.; Vroon, P.; Mercier, J.-C.; and Lin, C. Y. 1998. Texture-temperature-geochemistry relationship in the upper mantle as revealed from spinel peridotite xenoliths from Wangqing, NE China. J. Petrol. 39:469-493.

Yang, J. H.; Chung, S. L.; Zhai, M. G.; and Zhou, X. H. 2004. Geochemical and $\mathrm{Sr}-\mathrm{Nd}-\mathrm{Pb}$ isotopic compositions of mafic dikes from the Jiaodong Peninsula, China: evidence for vein-plus-peridotite melting in the lithospheric mantle. Lithos 73:145-160.

Ye, H.; Zhang, B.; and Mao, F. 1987. The Cenozoic tectonic evolution of the Great North China: two types of rifting and crustal necking in the Great North China and their tectonic implications. Tectonophysics 133:217-227.

Zhang, H. F.; Sun, M.; Zhou, X. H.; Fan, W. M.; Zhai, M. G.; and Yin, J. F. 2002. Mesozoic lithosphere destruction beneath the North China craton: evidence from major, trace element, and $\mathrm{Sr}-\mathrm{Nd}-\mathrm{Pb}$ isotope studies of Fangcheng basalts. Contrib. Mineral. Petrol. 144:241253.

Zhao, G. C.; Wilde, S. A.; Cawood, P. A.; and Sun, M. 2001. Archean blocks and their boundaries in the North China craton: lithological, geochemical, structural, and P-T path constraints and tectonic evolution. Precambrian Res. 107:45-73.

Zhi, X.; Song, Y.; Frey, F. A.; Feng, J.; and Zhai, M. 1990. Geochemistry of Hannuoba basalts, eastern China: constraints on the origin of continental alkalic and tholeiitic basalt. Chem. Geol. 88:1-33.

Zhou, X. H., and Armstrong, R. L. 1982. Cenozoic volcanic rocks of eastern China: secular and geographic trends in chemistry and strontium isotopic composition. Earth Planet. Sci. Lett. 59:301-329. 